DOI:https://doi.org/10.24127/ajpm.v10i2.3467

\title{
TEACHER'S DIFFICULTIES JUNIOR HIGH SCHOOL COMMUNICATION MATHEMATICS DURING ONLINE LEARNING
}

\author{
Rahmiliasari Samnufida ${ }^{1 *}$ Sugiman $^{2}$, Heri Retnawati ${ }^{3}$ \\ ${ }^{1 * 2,3}$ UniversitasNegeriYogyakata, Yogyakarta, Indonesia \\ E-mail: $\quad$ rahmiliasarisamnufida.2019@student.uny.ac.id ${ }^{\left.{ }^{*}\right)}$ \\ sugiman@uny.ac.id ${ }^{2}$ \\ heri_retnawati@uny.ac.id ${ }^{3)}$
}

Received 08 January 2021; Received in revised form 09 June 2021; Accepted 29 June 2021

\begin{abstract}
Communication gets into one of the $21^{\text {st }}$ Century skills in Framework PISA 2018 to be measured. In addition, the purpose of learning mathematics according Permendikbud is one of them is able to communicate ideas and able to compile mathematical evidence using with mathematical symbols. So, the teachers are demanded to foster student mathematical communication especially in current pandemic that implementations online learning. Therefore, the purpose of this study is to describe teacher's difficulties in fostering student mathematical communication during online learning. This study is qualitative research type of phenomenology. Data collected through interview whatsapp what with 12 teachers in South Sumatera. Data analysis uses Miles and Huberman namely: (1) data collection (2) data reduction and presentation; and (4) Draw conclusions. The result shows that there is several teachers' difficulty in fostering students' mathematical communication i.e : implementation of learning process, student conditions and technology, economics.
\end{abstract}

Keyword : Mathematics communication; online learning.

\begin{abstract}
Abstrak
Komunikasi masuk dalam salah satu keterampilan abad ke-21 di framework PISA 2018 yang akan diukur. Selain itu tujuan pembelajaran matematika menurut Permendikbud bahwa salah satunya siswa mampu mengkomunikasikan gagasan serta mampu menyusun bukti matematika dengan menggunakan simbol matematika. Sehingga guru di tuntut untuk meningkatkan komunikasi siswa khusus di masa pandemi sekarang yang menerapkan pembelajaran secara daring (online). Sehingga tujuan penelitian ini ialah untuk mendeskripsikan kesulitan guru dalam membantu perkembangan komunikasi matematis siswa selama pembelajaran online. Penelitian ini merupakan penelitian kualitatif jenis Fenomenalogi. Data dikumpulkan melalui wawancara via wa dengan 12 guru SMP Sumatera Selatan. Analisis data yang digunakan ialah Miles dan Huberman dengan tahapan (1) pengumpulan data;(2) reduksi data dan penyajian; dan (3) menarik kesimpulan. Hasil penelitian menunjukkan bahwa ada beberapa kesulitan guru dalam membantu perkembangan komunikasi matematis siswa yaitu : pelaksanaan proses pembelajaran, kondisi siswa dan ekonomi serta teknis pembelajaran online.
\end{abstract}

Kata kunci: Komunikasimatematis;pembelajaran online.

This is an open access article under the Creative Commons Attribution 4.0 International License

\section{INTRODUCTION}

Corona virus pandemic has entered Indonesia from March 2020 to the present. The entry of Covid-19 has had a bad impact on all countries including Indonesia, one of which is in the education sector. This is explained if the impact of the virus has affected many sectors, namely the economy, tourism, education and many more (SironYubaedi, et al, 2020). Before the entry of the Corona virus into 
Indonesia, the education process in Indonesia was running as usual, however, after the virus was detected, the government asked the Indonesian people to remain calm in facing this problem and keep their health. Corona Virus is a virus that attacks the respiratory system where the symptoms that are often found are fever, cough and runny nose. This virus spreads very quickly from one detected person to another. Therefore, the government limits activities, one of which limits the activities of the learning process, where previously learning was carried out face-to-face, but now the learning process must be done online. The government implements online learning to decide the chain of spreading the virus which can occur if the learning is conducted face-to-face. The Covid pandemic has increased widely and is evenly felt around the world. One of them is Germany also feels the same way as Indonesia, where schools are temporarily closed starting from March 2020, so that teachers in Germany face the need to adapt to online teaching (König et al., 2020). Teachers in Indonesia feel the same way. Online learning is a system that helps in the learning process that can be done not face-to-face but online (online) remotely using a platform(Firman \& Rahayu, 2020).

The Indonesian government asks educators, although the learning system must be done online, it will not be a barrier for them in educating the nation's children. As we know in 2021 there will be an International student assessment program (PISA) which is devoted to learning mathematics with assessments that refer to 21 st century skills that all students in the world must master, namely critical thinking, creativity, research and inquiry, self direction, information use, systems thinking, communication and reflection(OECD, 2018). In addition, Permendikbud number 58 explains that the goal of learning mathematics is that students are able to communicate ideas and be able to compile mathematical evidence through mathematical symbols. So from the 2018 PISA framework and the objectives of learning mathematics according to Permendikbud number 58 that students' mathematical communication is very important and must be owned by students in learning mathematics.

Mathematical communication is effective in increasing conceptual understanding, student achievement and reducing anxiety in students (Lomibao et al., 2016). A student can understand a mathematical concept if they already know mathematics well so that they can apply it and can solve a mathematical problem. Besides that, the same thing was also expressed by (Paridjo \& Waluya, 2017) that mathematical communication is ability of the student can express, explain, describe, hearing that take student on a deep understanding of mathematics, Mathematical communication is the ability of students to be able to express, explain and listen in order to make students understand mathematics. In addition, communication skills are also how a person can share ideas with an emphasis on speaking and writing skills. This is made clear by (Triana et al., 2019) that Mathematical communication is ability to demonstrate mathematical ideas and symbols both verbally in writing, picture or diagrams, Besides that, ZevenbergefJ. Dole \& Wright stated that in mathematics there are 5 communications, namely oral, written, digital, visual and symbolic. This agrees if communication is the 
ability of students to express mathematical ideas both orally and in writing.

Several previous studies have conducted research on mathematical communication if some students have difficulty communicating their ideas through symbols, tables and diagrams and tables.(Arnawa \& Wulandari, 2020). The same thing was also expressed (Yerizon et al., 2020)that students' mathematical communication skills are still not good because students still have difficulty conveying information such as ideas or ideas. Students who are able to solve a mathematical problem and are able to reason can already be said that they already have mathematical communication skills (Rangkuti, 2014). Then what about the condition of Covid-19 which requires the learning process to be carried out online. Whether the learning process carried out by the teacher can foster their mathematical communication skills during online learning. There are many applications that teachers can use to facilitate them in teaching such as Google, Zoom, WhatsApp, Web Blog, Edmodo, Moodle and others.

Therefore it is important for teachers to develop learning strategies that can help the learning process that is taking place. However, we know that in implementing online learning, there are so many obstacles or obstacles experienced by both teachers and students. So, this study will focus on the obstacles experienced by teachers in fostering student mathematical communication during online learning.

Based on the description above, the purpose of this study is to find out the opinions of state and private SMP and MTs teachers in South Sumatra about what are the obstacles for mathematics teachers in fostering student mathematical communication through online learning. In addition, this research is also used as input material as well as additional insight for Mathematics teachers in implementing online learning so that an effective online learning process can be created, and can foster students' abilities and not be boring for students.

\section{METHOD}

The study is a phenomenological study which is carried out with a qualitative approach. This study describes and finds out the barriers to junior high school mathematics teachers in South Sumatra in fostering mathematical communication and curiosity of junior high school students based on teacher experiences. The subjects in this study were 12 junior high school mathematics teachers from both public and private schools. The technique of collecting through interviews is used to get in-depth information on the problems at hand. Data analysis used was Miles and Huberman with the stages of (1) data collection (2) data reduction and presentation; and (4) draw conclusions. Broadly speaking, the analysis used is to record all problems or phenomena that occur in the field obtained through the results of previous interviews, Furthermore, the results of the interview will be reviewed and separate data that are considered to have the same statement, describe the classified data by paying attention to the focus of this research and finally make the final analysis in the form of a conclusion to the problem. The interview aspect of this research is mathematical communication skills which include: (1) expressing ideas through conversation, writing, demonstrations, and visual 
depicting in different types; (2) understand, interpret and evaluate the ideas presented in writing or in visual form; (3) constructing, interpreting, and linking various forms of representation of ideas and their relationships; (4) make observations and concectures, formulate questions, carry and evaluate information; (5) produce and state arguments persuasively (Greenes and Schulma). So, the results of the interview will be reduced to answer the objectives of the study.

\section{RESULTS AND DISCUSSION}

This study uses the analysis stages of Miles and Huberman with details, (1) data collection (2) data reduction and data presentation; and (4) Draw conclusions. This research was conducted by interview involving 12 Mathematics teachers in South Sumatra Province. The following are the details of the research results in stages from Miles and Huberman.

1. Data collection

This study was obtained from the results of interviews with 12 mathematics teachers with interview instruments covering aspects of mathematical communication from (Greenes and Schulma). From the results of the interview, it was found that the teacher's obstacles in growing student mathematical communication during online learning.

2. Data Reduction and Presentation From the results of interviews and obtained some teacher barriers and research reduces data by grouping the results of these interviews. The following are the results of the reduction from the results of interviews with the 12 Mathematics teachers.

\section{Implementation of the learning process}

The current implementation of learning must be done remotely (online) which is a policy carried out by the Indonesian government to minimize the spread of the corona virus that is still happening in our country. So far it has not occurred to us that this virus will enter our country and make all activities restricted. This is based on the Ministry of Education and Culture by issuing Circular No. 4 regarding the Implementation of Education Policies in the Emergency Period for the Spread of COVID-19 starting from March 24, 2020 until now. The implementation of this online learning has been carried out for almost \pm 2 semesters. With this policy, the government demands all educators to design online learning processes. Teachers do not think before that they will teach with the current system. There are some teachers who accept and understand online learning, but there are also teachers who do not understand what online learning is like. There are many obstacles experienced by teachers while implementing/implementing this online learning process. The teacher said that distance learning made them confused about what things they should prepare, because so far they only thought of coming to school to teach directly in front of their students. But now they have to adapt to the name of technology. From the results of interviews with mathematics teachers, it was found that the common problems of online learning are the limitations of teachers in mastering technology and the limited condition of internet signals. This is in line with the results of research from There are many obstacles experienced by teachers while implementing/implementing this online learning process. The teacher said that 
distance learning made them confused about what things they should prepare, because so far they only thought of coming to school to teach directly in front of their students. But now they have to adapt to the name of technology. From the results of interviews with mathematics teachers, it was found that the common problems of online learning are the limitations of teachers in mastering technology and the limited condition of internet signals. This is in line with the results of research from There are many obstacles experienced by teachers while implementing/implementing this online learning process. The teacher said that distance learning made them confused about what things they should prepare, because so far they only thought of coming to school to teach directly in front of their students. But now they have to adapt to the name of technology. From the results of interviews with mathematics teachers, it was found that the common problems of online learning are the limitations of teachers in mastering technology and the limited condition of internet signals. This is in line with the results of research from because so far they only think of coming to school to teach directly in front of their students. But now they have to adapt to the name of technology. From the results of interviews with mathematics teachers, it was found that the common problems of online learning are the limitations of teachers in mastering technology and the limited condition of internet signals. This is in line with the results of research from because so far they only think of coming to school to teach directly in front of their students. But now they have to adapt to the name of technology. From the results of interviews with mathematics teachers, it was found that the common problems of online learning are the limitations of teachers in mastering technology and the limited condition of internet signals. This is in line with the results of research from(Rigianti, 2020)which states that a number of teachers experience problems including learning applications, internet networks, learning management, assessment and supervision. Besides that, the same thing was said(Sankar et al., 2020)Several variables that influence learning quality of learning are administrative support, course content, course design, instructor characteristics, learner characteristics, social support and technological support. In addition to these problems, there are also obstacles for teachers during the online learning process, which lies in the implementation of learning. Some teachers revealed that they were still confused about how to operate technology such as google meet, $b$ esides being confused about operating technology, the teacher was also confused in designing online learning that was suitable for the material to be taught, because according to them online learning was more time consuming than face-to-face learning. . Another obstacle was also revealed that there were still few students responding to statements that were sometimes given by the teacher, so sometimes the teacher is like talking to himself without being responded to by the students and the teacher doesn't even know what activities the students are doing during the learning process because most students sometimes when they're on gmeet rarely activate the camera so the teacher doesn't know whether the students are paying attention or not. Some teachers said that "if only face-toface learning, no one asks any 
questions, let alone online learning like this" the statement was expressed by several teachers. so it can be said that during this online learning students are less active in learning so there is no curiosity about what they are learning. Teachers are also confused during this learning often ask whether the silence of their students in learning means that they understand the material being taught or vice versa they are embarrassed to ask and prefer to be silent. Here are some statements from several teachers in responding to the implementation of learning as follows:

"Ada beberaa yang merespon jika temannya bertanya/berkomentar tapi ada juga yang hanya diam saja (some students are respond to answer if their friend give comments or just silent)"

"Kami tidak mengetahui apakah siswa mengerjakan $P R$ dibantu keluarga atau sendiri (we (teachers) don't know whether they are assisted in solving problems by their families or doing it themselves)"

"Selama pembelajaran siswa tidak pernah jarang sekali siswa untuk bertanya (during the learning process, students rarely ask about material presented)

"Selama pembelajaran kami sulit untuk menilai siswa apakah mereka sudah mengembangkan komunikasi mereka, karena hanya beberapa siswa yang merespon kami selama proses pembelajaran kami (During online learning, we cannot judge if all students have developed their communication because only a few have responded and who respond cannot be said if they are developed their communication)"

"kami bingung proses pembelajaran online ini apa yang harus kami lakukan. Untuk kami guru senior beberapa kesulitan dalam menggunakan teknologi, sehingga hanya member materi dan penjelasan menggunakan whatsapp group saja (sometimes, we are confused with online learning what should we do, because several teacher senior are still confused about techonology. So, they are only giveassigments to thought whatsapp group)"

So from several statements from some of these teachers, it can be said that the obstacle for teachers during online learning is the implementation of the online learning process which makes teachers still have to adapt to what is called technology. To overcome some of these obstacles, the need for socialization for online learning has to be carried out by the government in order to assist teachers in carrying out the online learning process. Commision DPR RI said that distance learning could be applied permanently after this covid was over. The minister also said this could be the basis for utilizing technology. So with that statement it is necessary to conduct training socialization for teachers to help them how to design online learning by utilizing good technology to achieve a learning goal.

\section{Student Condition}

The success of a learning process is also influenced by the condition of students. At times like the current conditions, it is necessary for teachers to pay attention to the condition of students in online learning. As research results(Yunitasari \& Hanifah, 2020)that learning is less interesting unlike faceto-face learning so that it makes students feel bored quickly so that it will affect student interest in learning. This is in line with the results of researcher interviews with several teachers who said that during the online 
learning process, student activity was greatly reduced. They rarely comment or have an opinion on what is conveyed. In addition, during the learning process sometimes students only enter the whatsapp group but rarely appear to comment or give opinions. So it is difficult for teachers to give an assessment of students who are not active, but there are some students who ask questions and express their ideas, so teachers are still eager to teach with active students. In addition, when the teacher asks students to study together, they meet at google meet but there are some who enter and some do not. During Gmeet students also don't want to turn on the camera so the teacher doesn't know what students are doing at that time whether they are paying attention or they just log in and they just play Here are some statements from several teachers in responding to the implementation of learning as follows:

"Ada beberapa siswa bisa mengungkapkan ide mereka namun ada juga siswa yang hanya diam saja dan ketika namanya dipanggil siswa tersebut tidak merespon (some of the have been showed their ideas if they given a problem and some students are just keep quiet and than just respond if they are called)"

"kami guru tidak mengetahui kegiatan siswa selama pembelajaran online berlangsung, sehingga membuat mereka tidak merespon kami (Teachers don't know their students in online learning procces so they are don't respond during dicussions)"

"ada beberapa siswa yang telat masuk diforum diskusi dan ada juga yang tidak masuk sama sekali di forum diskusi selama proses pembelajaran (sometimes there are students who enter to whatsapp groupmeeting or discussion group to late and some don't enter in meeting. So they aren't follow the learing process)"

So from the results of the interview above, it can be said that during the online learning process during the COVID-19 pandemic, students were not serious about participating in the learning process, which could be seen from some students not participating in learning, besides that students did not respond to teachers when asked questions or problems resulting in one-sided learning and also during learning students rarely activate the camera so that the teacher does not know what activities the students are doing.

\section{Student Economics and Online Learning Technician}

It is undeniable that during online learning are required Smartphone as their support device to online learning. In addition to having to have a smartphone, students must also have a data (internet) package so they can connect to the whatsapp group or enter the google meet account. However, in reality, in the field, this becomes an obstacle for students in participating in the learning process, because there are still some areas that have not been touched by the internet, making students and teachers living in the area confused in carrying out the learning process. In addition, there are also some students who have family economic conditions that are not sufficient to meet the needs of their children in participating in the online learning process so that students cannot enter and join whatsapp and gmeet groups. This is in line with the 
results of interviews from several teachers who said that not all students have cellphones that can facilitate them to study online. Other things were also revealed from the research results(Febrianto et al., 2020)who said that online learning, especially on the island of Madura, was not only constrained by technical problems and facilities, but human resources that needed to be encouraged to accept this latest learning model. Students think that current learning is not useful because there are several obstacles such as geographical areas such as rural areas that are difficult to access the internet. In addition, they cannot afford to buy internet quota because there are several applications that require large quotas. This is an obstacle for students, especially for students whose family economy is not sufficient. Here are some statements from several teachers in response to the economic conditions of students and technicians in the learning process as follows:

"tidak semua siswa bisa mengikuti pembelajaran online karena kondisi ekonomi keluarga yang tidak bisa memfasilitasi proses pembelajaran online (Difficulties exist, one of which is not all students are able to take part in learning process because economic conditions do not facilitate them in online learning)"

"ada beberapa siswa tidak memiliki handphone dan mereka meminjam handphone tetangga/teman mereka (There are some students who don't have cellphones and they ride with their neighbors as with their friends)"

"Kadang terkendala dengan kondisi
internet yang tidak stabil selama
menggunakan google meet
(Sometimes it is constrained by lost internet connection because the teacher often meeting in google meet for seeing their students in learning)".

After presenting the data, it was concluded that the teacher's obstacles in growing students' mathematical communication skills during online learning were divided into several parts, namely (1) Implementation of the learning process, (2) Student conditions, (3) Student economics and online learning technicians.

So with statements from several teachers and the results of previous research, it can be said that the obstacles experienced by teachers during online learning are obstacles to internal technicians and also the economic conditions of students who are not sufficient for them to take part in the online learning process.

First, based on the results of interviews with several Junior High School Mathematics teachers is obtained if the obstacle for them in improving students' mathematical communication during online learning lies in the readiness of online learning both from the teacher and students. The readiness of teachers in designing online learning is a particular difficulty experienced by teachers because some teachers still do not understand about technology. They said that during online learning sometimes they could only use whatsapp group by giving assignments / exercises to students and asking them to solve the assignment. This results in the teacher not knowing the development of students' mathematical communication in solving problems. Besides that, sometimes the teacher gives a problem and asks students to discuss about the problems in the WhatsApp group, but students just read without comment or 
giving opinions on the ideas they get. So that learning only occurs on one side. Apart from teacher readiness, there are other obstacles from student readiness. the readiness of this student to enter the second part, namely the condition of the student At the time of the learning process the teacher did not know the student's activities during the online learning process, only a few students responded to the questions expressed by the teacher and some were just silent and did not give any response. This causes teachers to be unable to measure students' abilities and student effectiveness during learning. In addition, if the teacher asks students to join google meet to make presentations and students just keep quiet without giving feedback on what is explained by the teacher. This causes the teacher to feel that their learning objectives cannot be maximized. And the last obstacle faced by teachers also lies in the technician and student economics section. we know that implementing online learning now requires students to have smartphones to facilitate their learning process. However, as we know, not all students have sufficient economics. The same thing happened to students in some areas where they did not have smartphones that supported them for online learning so that some of them asked for help with their neighbors to join the WA group. In addition to requiring students to have a smartphone, students must also have an internet quota so they can access learning and there are also some areas where the internal signal is not stable, it often disappears. This happens when they are carrying out a google meet with their teachers and friends. So, the three parts become to influence online learning by the teacher in fostering student mathematical communication

The results of this study are in line with the results of previous research, if what is an obstacle to online learning is the lack of student interest in learning mathematics, students are lazy to memorize formulas, the difference is face-to-face learning systems online, teachers find it difficult to develop material in books and also with The current online learning system has not yet maximized the learning process due to time, support systems such as the internet and the condition of students (Fauzi et al., 2020; Ilmadi \& Zarista, 2020). Besides that, it was also similarly expressed by(Anugrahana, 2020) which he said if the involvement of students in learning was not optimal where the results were obtained if $50 \%$ of students who were actively involved were fully involved in the learning process, $33 \%$ of students who were actively involved and $17 \%$ of students who were less active and less participating in online learning and also (Hamid et al., 2020). They said that during online learning students felt that their application in the learning process had not been fully effective, these results were also in line with the results of the study. (Trenholm \& Peschke, 2020)that during full online learning there was a lack of discussion that resulted in students' mathematical communication not being maximized. Some of the research results also state that what is a drawback in distance learning in this case is online instability of the internet network and there are still some students who do not have internet access during the learning process (Handayani, 2020; Kusumaningrum \& Wijayanto, 2020; Mailizar et al., 2020). In addition to 
these obstacles, there are other obstacles in online learning where the economic conditions of students who do not support them when learning online are expressed (Areepattamannil, 2014; $\mathrm{Hu}$ et al., 2018; Lubienski \& Lubienski, 2005) which says if the socioeconomic or background of students in economics affects mathematics learning outcomes.

\section{CONCLUSION AND SUGGESTION}

This research was conducted to answer about the obstacles experienced by Mathematics teachers, especially in South Sumatra Province, to online learning in fostering students' mathematical communication. It was found that the obstacles experienced by the research teacher were divided into 3 parts, namely the implementation of the learning process, student conditions and finally online learning technicians and student economics. so that from the results of these findings it can help, especially in the world of education to carry out socialization for the online learning process and how to design online learning that is attractive and does not bore students in following the learning process. The results of this study are expected to be used as a reference for further research. However, the shortcomings in this study lie in the small number of subjects and also this research is only focused on the junior high school level. So for further research suggestions, it is hoped that the research subject will be wider and focused in higher level.

\section{REFERENCES}

Anugrahana, A. (2020). Barriers, Solutions and Hopes: Online Learning During the Covid-19 Pandemic by Elementary School Teachers. Scholaria: Journal of Education and Culture, 10 (3), 282- 289.https://doi.org/10.24246/j.js.20 20.v10.i3.p282-289

Areepattamannil, S. (2014). International Note: What factors are associated with reading, mathematics, and science literacy of Indian adolescents? A multilevel examination. Journal of Adolescence, 37(4), 367-372. https://doi.org/10.1016/j.adolescenc e.2014.02.007

Arnawa, I. M., \& Wulandari, L. (2020). The Effect of Numbered Heads Together Cooperative Model on Students' Mathematical Communication Ability. AKSIOMA: Journal of Mathematics Education Study Program, 9 (4), 1048. https://doi.org/10.24127/ajpm.v9i4. 2945.

Fauzi, A., Sawitri, D, \& Syahrir, S. (2020). Teachers' Difficulties in Learning Mathematics in Elementary Schools. Mandala Education Scientific Journal, 6 (1), 142-148. https://doi.org/10.36312/jime.v6i1. 1119.

Febrianto, PT, Mas'udah, S, \& Megasari, LA (2020). Implementation of online learning during the covid-19 pandemic on Madura Island, Indonesia. International Journal of Learning, Teaching and Educational Research, 19 (8), 233254.

https://doi.org/10.26803/ijlter.19.8. 13

Firman, F, \& Rahayu, S. (2020). Online Learning Amid the Covid-19 Pandemic. Indonesian Journal of Educational Science (IJES), 2 (2), 81-89. https://doi.org/10.31605/ijes.v2i2.6 59

Hamid, R., Sentryo, I., \& Hasan, S. (2020). Online learning and its problems in the Covid-19 
DOI:https://doi.org/10.24127/ajpm.v10i2.3467

emergency period. Prima Educasia Journal, 8 (1), 86-95. https://doi.org/10.21831/jpe.v8i1.32 165.

Handayani, L. (2020). Advantages, Constraints and Online Learning Solutions During the Covid-19 Pandemic: An Exploratory Study at SMPN 3 Bae Kudus Lina Handayani. Journal of Industrial Engineering \& Management Research, 1 (2), 16.

Hu, X., Gong, Y., Lai, C., \& Leung, FKS (2018). The relationship between ICT and student literacy in mathematics, reading, and science across 44 countries: A multilevel analysis. Computers and Education, 125 (September 2017), 1-13. https://doi.org/10.1016/j.compedu.2 018.05.021

Ilmadi, \& Zarista R. H., ASG (2020). the Effectiveness of Online Learning for Mathematics Students During the Covid-19 Pandemic (Case Study-Mathematics Study Program, Pamulang University). 04 (02), 1273-1282.

König, J., Jäger-Biela, DJ, \& Glutsch, N. (2020). Adapting to online teaching during COVID-19 school closure: teacher education and teacher competence effects among early career teachers in Germany. European Journal of Teacher Education, 43 (4), 608-622. https://doi.org/10.1080/02619768.2 020.1809650

Kusumaningrum, B, \& Wijayanto, Z. (2020). Is Online Mathematics Learning Effective? (Case Studies on Learning During the Covid-19 Pandemic). Kreano, Journal of Creative-Innovative Mathematics, 11 (2), 139-146. https://journal.unnes.ac.id/nju/index .php/kreano/article/view/25029

Lomibao, LS, Luna, CA, \& Namoco, RA (2016). The Influence of
Mathematical Communication on Students' Mathematics Performance and Anxiety. American Journal of Educational Research, 4 (5), 378382.

https://doi.org/10.12691/education4-5-3.

Lubienski, ST, \& Lubienski, C. (2005). A new look at public and private schools: Student background and mathematics achievement. Phi Delta Kappan, 86 (9), 696-699. https://doi.org/10.1177/0031721705 08600914.

Mailizar, Almanthari, A., Maulina, S., \& Bruce, S. (2020). Secondary school mathematics teachers' views on elearning implementation barriers during the COVID-19 pandemic: The case of Indonesia. Eurasia Journal of Mathematics, Science and Technology Education, 16 (7). https://doi.org/10.29333/EJMSTE/8 240.

OECD. (2018). PISA 2015 Result in Focus. Kanada: OECD. https://www.oecd.org

Paridjo, P., \& Waluya, SB (2017). Analysis Mathematical Communication Skills Students In The Matter Algebra Based Nctm. IOSR Journal of Mathematics, 13 (01), 60-66. https://doi.org/10.9790/57281301056066

Rigianti, HA (2020). The Constraints Of Basic Teacher Learning For Primary Schools In Banjarnegara District. Elementary School, 7 (2), 297-302.

Sankar, J., R, K., John, J., Menon, N., Elumalai, K., Alqahtani, M., \& Abumelha, M. (2020). Factors Affecting the Quality of E-Learning During the COVID-19 Pandemic from the Perspective of Higher Education Students. Journal of Information Technology Education: Research, 19 (1), 731-753. 
DOI:https://doi.org/10.24127/ajpm.v10i2.3467

https://www.learntechlib.org/p/218 286.

SironYubaedi, et al, (2020). Factors Affecting the Adoption ELearning in Indonesia: Lesson from Covid-19. Journal of Technology and Science Education, $10(2)$, http://dx.doi.org/10.3926/jotse.10 25.

Trenholm, S., \& Peschke, J. (2020). Teaching undergraduate mathematics fully online: a review from the perspective of communities of practice. International Journal of Educational Technology in Higher Education, 17 https://doi.org/10.1186/s41239020-00215-0.

Triana, M., Zubainur, CM, \& Bahrun, B. (2019). Students' Mathematical Communication Ability through the Brain-Based Learning Approach using Autograph. JRAMathEdu:
Journal of Research and Advances in Mathematics Education, 1 (1), 110.

https://doi.org/10.23917/jramathedu .v1i1.6972.

Yerizon, Y., Putri, YU, Musdi, E., \& Permana, D. (2020). The Effectiveness of Mathematics Learning Tools Based on Contextual Teaching and Learning Approaches on Mathematical Communication Skills. AKSIOMA: Journal of Mathematics Education Study Program, 9 (1), 205. https://doi.org/10.24127/ajpm.v9i1. 2305

Yunitasari, R., \& Hanifah, U. (2020). The Influence of Online Learning on Student Learning Interest during the Covid 19 Period. Educative: Journal of Educational Sciences, 2 (3), 232 243.https://doi.org/10.31004/edukat if.v2i3.142. 